\title{
The role of provenance in the diagenesis of siliciclastic reservoirs in the Upper Triassic Yanchang Formation, Ordos Basin, China
}

\author{
Ding Xiaoqi ${ }^{1,2 *}$, Han Meimei ${ }^{2}$ and Zhang Shaonan ${ }^{2}$ \\ ${ }^{1}$ College of Energy Resources, Chengdu University of Technology, Sichuan 610059, China \\ ${ }^{2}$ State Key Laboratory of Oil and Gas Reservoir Geology and Exploitation, Southwest Petroleum University, Sichuan \\ 610500, China
}

(C) China University of Petroleum (Beijing) and Springer-Verlag Berlin Heidelberg 2013

\begin{abstract}
A better understanding of the controls on reservoir quality has become essential in the petroleum exploration in recent years. Determining the original composition of the sediment framework is important not only for paleogeographic reconstructions, but it is also vital for predicting the nature of physical and chemical diagenesis of the potential reservoirs. Depositional setting and diagenesis are important factors in controlling the type and quality of most siliciclastic reservoirs. We studied the Upper Triassic Chang 8 and 6 members, where the relationship between sediment provenance and diagenesis was examined. The study attempts to clarify sediment provenance and post-depositional diagenetic modifications of the sandstones through systematic analytical methods including petrographic macro- and microscopic analysis of grain and heavy mineral types, and measurements of the palaeocurrent direction of the Yanchang Formation sediments in the outcrops in order to determine the provenance of the studied sediments. Furthermore, the relationship between framework grains, pore types and diagenesis of the sediments was analyzed by thin section petrographic characterization using a polarizing microscope. Additionally, a JEOL JSM-T330 scanning electron microscope (SEM) equipped with a digital imaging system was used to investigate the habits and textural relationships of diagenetic minerals. On the basis of our results, we believe that sediment provenance is a significant factor which controls the type and degree of diagenesis which may be expected in sandstones. In the Chang 8 and 6 members, the formation of chlorite rims and laumontite cement was observed where volcanic rock fragments constitute a large part of the framework grains. Furthermore, high biotite content provides abundant iron and magnesium and enables the formation of chlorite rims due to biotite hydrolysis. In addition, ductile deformation of biotite leads to strong mechanical compaction of the sediments. Conversely, high feldspar content diminishes the degree of mechanical compaction, however the dissolution of feldspar minerals in sandstones is commonly observed. Apart from feldspars, quartz and other rigid framework grains highly control the degree of mechanical compaction during the initial stage of burial $(0-2 \mathrm{~km})$.
\end{abstract}

Key words: Provenance, diagenesis, tight sandstones, Yanchang Formation, Ordos Basin

\section{Introduction}

The key properties of hydrocarbon reservoirs are porosity and permeability. These properties control not only the amount of gas or oil in place but also rate of petroleum extraction. The success of many hydrocarbon exploration efforts depends to a large extent on accurate prediction of sandstone reservoir properties. Additionally, an accurate risk assessment is a critical stage in exploration, where reservoirs have been buried to depths greater than $3,000 \mathrm{~m}$ and have been exposed to temperatures greater than $100{ }^{\circ} \mathrm{C}$ (Taylor et

* Corresponding author. email: xiaoqiding@qq.com

Received March 8, 2012 al, 2010).

It is commonly believed that reservoir quality is determined by sedimentary facies type and distribution, diagenesis processes and also, to some extent by fracturing, such as in case of siliciclastic reservoirs.

Mechanical and chemical stability of sandstones is strongly linked to grain composition (De Ros et al, 1994; Bloch et al, 2002). The detrital composition of sandstones is controlled by the geological evolution of the provenance, including rock types and tectonics, palaeoclimatic conditions and depositional processes (Zuffa et al, 1995; Morad et al, 2000).

The degree of primary porosity is controlled by grain size, sorting, roundness and composition as well as by 
matrix content. All of the mentioned characteristics are controlled by depositional conditions and they further govern the type and degree of diagenesis, which is the key dynamic affecting reservoir quality. The extrinsic parameters controlling diagenesis processes include the geothermal gradient, fluid chemistry and current subsurface depth. The intrinsic parameters are the composition, sorting and surface textures of the framework grains. The grain composition of siliciclastic sediments is strongly influenced by sediment source and depositional conditions present within the tectonic regime at the time of deposition. Recognition of changes in composition resulting from variations in provenance type has profound potential for improving accurate prediction of reservoir quality.

Anomalously high porosity and permeability in deeply buried reservoirs can have a significant impact on the production rate. Anomalously high porosity and permeability in siliciclastic reservoirs can be preserved or developed due to weak compaction, a low degree of cementation and/ or enhanced dissolution. Compaction of the sediments is greatly controlled by grain composition and burial. Sandstone reservoirs with high content of ductile grains, such as shale clasts, biotite or lithic fragments experience more extensive compaction (Pittman and Larese, 1991; Bloch et al, 2002; Paxton et al, 2002; Li et al, 2006). Some forms of minerals, such as chlorite rims and microquartz, may act as inhibitors of later quartz overgrowth and compaction (Ehrenberg, 1993; Anjos et al, 2003; Berger et al, 2009; Lander and Bonnell, 2010). A degree of dissolution which may lead to the enhancement of porosity is also controlled by the composition of the sediment. For instance, feldspars, volcanic and carbonate rock fragments are more likely to be dissolved during weathering and diagenesis processes than quartz, metamorphic rock fragments and other sedimentary rock fragments. Nevertheless, during an early stage of diagenesis only dissolution of plagioclase takes place since it is unstable in low temperatures, whereas $\mathrm{K}$-feldspars are unstable in high temperatures therefore are dissolved in the later stage of diagenesis (Lander and Bonnell, 2010).

Mature sandstones are both mechanically and chemically stable and have potential to form good reservoirs at depths shallower than $3 \mathrm{~km}$ (Bloch et al, 2002; Warren and Pulham, 2001). Conversely, at depths greater than $3 \mathrm{~km}$ reservoir porosity and permeability may be lost substantially because of mesogenetic pressure dissolution and quartz cementation. Sandstones which are rich in rock fragments are commonly mechanically and chemically unstable. Volcanic rock fragments are chemically unstable and tend to dissolve or alter into smectite and chlorite, zeolites and silica during diagenesis (Hawlader, 1990; Pirrie et al, 1994). Furthermore, feldspar-rich sandstones are mechanically stable however chemically unstable. For instance, under prolonged interaction with meteoric water, feldspar grains undergo dissolution and kaolinization. Carbonate rock fragments, such as limestone and dolostone fragments promote nucleation and growth of carbonate cements and thus contribute to porosity and permeability deterioration. Carbonate rock fragments also contribute to porosity reduction because of the chemical compaction they enhance (Fontana et al, 1986; 1989; Mansurbeg et al, 2009; Caja et al, 2010).

\section{Geological settings}

The Ordos Basin is situated in the middle part of mainland China (Fig. 1) and it covers an area of $250,000 \mathrm{~km}^{2}$ with a sediment thickness of 4,000-6,000 m. It is a typical polycyclic sedimentary basin, including Lower Paleozoic, Upper Paleozoic and Mesozoic sequences. The Upper Triassic Yanchang Formation consists of deltaic and lacustrine siliciclastic sediments deposited in a humid climate. Many provenances exist along the margin of the basin: the Yinshan Uplift to the north, Alxa Uplift to the northwest, Qinling Uplift to the south and Longxi Uplift to the southwest. The Yanchang Formation is subdivided into ten individual members (Fig. 2).

Dark-grey lacustrine mudstones of the Chang 7 Member are the source rocks in the Ordos Basin, supported by the recent oil-source rock correlation studies. All discovered Triassic oil fields are distributed within the range of the Chang 7 Member favourable source kitchen. Petroleum from the source rocks was expelled upward and downward into adjacent reservoirs. Therefore, Chang 6 and Chang 8 members which are adjacent source rocks are also favourable for hydrocarbon accumulations.

The Chang 8 and 6 members of the Upper Triassic are the main targets in petroleum exploration and development in the recent years in the Ordos Basin, forming many prolific petroleum provinces. The reservoirs of the Chang 8 and 6 members are dominated by tight sandstones with an average porosity of $10 \%$ and permeability of $0.4 \times 1^{-3} \mu \mathrm{m}^{2}$. The basin dips gently to the west with an angle of less than $1^{\circ}$. Faults and anticlines were not developed in the most parts of the basin therefore stratigraphic traps are the dominant trap style in this petroleum system.

Three typical hydrocarbon fields from the Ordos Basin have been selected for analysis in this study (Fig. 1). The ZJ field is located in the south-western part of the Ordos Basin and has producing oil in the Chang 8 and 6 members. The sediment provenance was the Longxi Uplift situated in Gansu and Shaanxi provinces. The FX field is situated in the eastern part of the basin. Despite of oil having been found, the field is not economically prospective. The sediment provenance was the Yinshan Uplift situated in Inner Mongolia to the north. Lastly, the JY field, located in the north-western part of the Ordos Basin has been found to be a prolific hydrocarbon field. The sediment provenance was the Alxa Uplift situated in Ningxia province to the northwest.

\section{Sampling and analytical methods}

300 samples were obtained from 15 cores from the three study fields. Thin sections were cut from slices of the coreslab face. The samples were then impregnated with blue epoxy resin to highlight pore spaces when viewed under the microscope. 200-300 counts per section were made for composition analysis, and 100 counts per section were made for grain size and sorting examination. 32 samples 


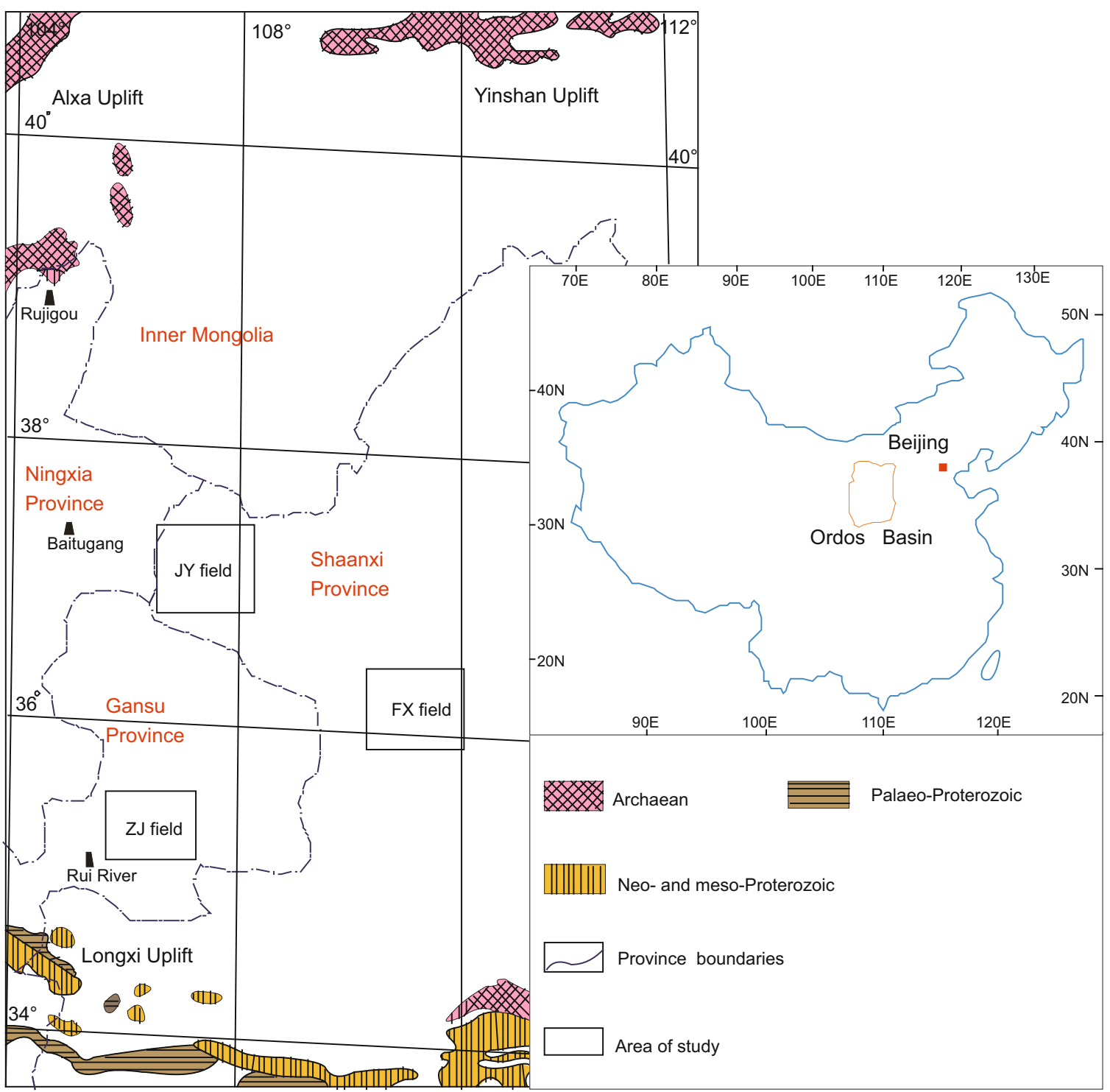

Fig. 1 Outcrops on the basin margin and location map of the area of interest

\begin{tabular}{|c|c|c|}
\hline \multirow{2}{*}{ Lower Jurassic } & \multicolumn{2}{|c|}{ Yanan Formation (250-350 m) } \\
\hline & \multicolumn{2}{|c|}{ Fuxian Formation $(0-150 \mathrm{~m})$} \\
\hline \multirow{10}{*}{ Upper Triassic } & \multirow{10}{*}{$\begin{array}{l}\text { Yanchang } \\
\text { Formation } \\
(800-1400 \mathrm{~m})\end{array}$} & Member 1 \\
\hline & & Member 2 \\
\hline & & Member 3 \\
\hline & & Member 4 \\
\hline & & Member 5 \\
\hline & & Member 6 \\
\hline & & Member 7 \\
\hline & & Member 8 \\
\hline & & Member 9 \\
\hline & & Member 10 \\
\hline Middle Triassic & Zhifang Formatio & \\
\hline
\end{tabular}

Fig. 2 Subdivision and stratigraphic nomenclature of the Yanchang Formation in the Ordos Basin were studied using a scanning electron microscope equipped with an energy dispersive X-ray spectrometer. A total of 22 samples were analyzed for heavy minerals content.

\section{Results}

\subsection{Petrology}

Petrology of the Chang 8 and 6 members sandstones in the JY field, ZJ field and FX field was studied by thin section analysis and scanning electron microscopy (SEM). The characteristics of the sandstones are described below (Table 1).

\section{JY Field}

The depositional environment of the Chang 8 and 6 members encountered in the area of the JY field is a delta setting, hence reservoirs exist within distributary channel sandstones. The sandstones have been classified as lithic arkose and feldspathic litharenite. The grain size of the sandstones is fine to medium $(0.26-0.46 \mathrm{~mm})$ and they are composed primarily of quartz (dominantly monocrystalline 
Table 1 Statistical summary of the petrographic parameters of Chang 8 and 6 members sandstones

\begin{tabular}{|c|c|c|c|c|c|c|c|c|c|c|}
\hline & \multirow{2}{*}{$\begin{array}{l}\text { Components } \\
\text { and texture }\end{array}$} & \multicolumn{3}{|c|}{ JY field $(n=83)$} & \multicolumn{3}{|c|}{$Z J$ field $(n=155)$} & \multicolumn{3}{|c|}{ FX field $(n=92)$} \\
\hline & & $\operatorname{Max}, \%$ & Min, $\%$ & Aver, $\%$ & Max, \% & Min, $\%$ & Aver, $\%$ & Max, \% & Min, $\%$ & Aver, $\%$ \\
\hline \multirow{8}{*}{$\begin{array}{c}\text { Detrital } \\
\text { fragments } \\
(100 \%)\end{array}$} & Quartz polycrystalline & 14 & 6 & 8 & 15 & 6 & 12 & 12 & 6 & 8 \\
\hline & Plagioclase & 25 & 13 & 20 & 18 & 10 & 18 & 41 & 25 & 34 \\
\hline & K-feldspar & 12 & 7 & 10 & 19 & 10 & 15 & 22 & 12 & 15 \\
\hline & Volcanic rock & 13 & 3 & 7 & 16 & 6 & 9 & 2 & 0 & 1 \\
\hline & Metamorphic rock & 30 & 8 & 21 & 18 & 4 & 10 & 10 & 3 & 5 \\
\hline & Sedimentary rock & 8 & 1 & 4 & 5 & 0 & 2 & 2 & 0 & 1 \\
\hline & Heavy minerals & 5 & 1 & 2 & 4 & 1 & 1 & 4 & 1 & 2 \\
\hline & Mica & 12 & 0 & 2 & 8 & 1 & 2 & 18 & 2 & 6 \\
\hline \multirow{6}{*}{ Cements } & Calcite & 31 & 0 & 6 & 33 & 0 & 5 & 30 & 1 & 6 \\
\hline & Ankerite & 5 & 0 & 1 & 6 & 0 & 1 & 3 & 0 & 1 \\
\hline & Chlorite & 5 & 0 & 3 & 2 & 0 & 1 & 8 & 2 & 6 \\
\hline & Kaolinite & 9 & 0 & 2 & 7 & 0 & 2 & 2 & 0 & 1 \\
\hline & Illite & 5 & 1 & 2 & 7 & 2 & 4 & 15 & 3 & 6 \\
\hline & Quartz overgrowth & 6 & 0 & 2 & 5 & 0 & 2 & 1 & 3 & 2 \\
\hline \multirow{2}{*}{ Texture } & Sorting & 1.40 & 0.30 & 0.80 & 0.80 & 0.30 & 0.45 & 0.60 & 0.20 & 0.40 \\
\hline & Grain size, mm & 0.46 & & 0.26 & 0.33 & & 0.21 & 0.28 & & 0.13 \\
\hline
\end{tabular}

Notes: $n$ is the total number of samples

quartz), feldspars (dominantly plagioclase with some $\mathrm{K}$-feldspars), rock fragments such as phyllite, quartzite and volcanic rock fragments (average 7\%) and traces of biotite. Calcite and ferroan calcite are the main types of carbonate cements (average $8 \%$, up to $31 \%$ ), but trace ankerites also exist. Authigenic clay minerals (average 7\%) include chlorite, kaolinite and illite that occur as pore-lining rims and porefilling cement. Chlorite commonly occurs as interlocked pseudohexagonal crystals in the delta front sediments and as thin and discontinuous rims. Kaolinite occurs as booklet and vermicular aggregates in delta plain and delta front sediments. Illite occurs as pore-lining rims and pore-filling cements and as replacement of mud matrix and detrital feldspar. The volume of quartz overgrowths is very low and laumontite is rare.

\section{ZJ Field}

The Chang 8 and 6 member sandstones in the ZJ field were also deposited in delta front setting environments. Therefore similar to the JY field, the main reservoirs exist within distributary channels, but also in delta front mouth bars. The grain sorting is good and the grain size ranges from $0.21 \mathrm{~mm}$ to $0.33 \mathrm{~mm}$. The sandstones have been classified as lithic arkose and feldspathic litharenite. The quartz content is higher than that in the JY field deposits where the monocrystalline quartz concentration is $31 \%$ and the polycrystalline quartz level is $12 \%$. Other grains are mainly feldspars (plagioclase and K-feldspars, $18 \%$ and $15 \%$ respectively), and rock fragments such as phyllite, slate, quartzite and plutonic rock fragments and traces of mica (2\%). Calcite and ferroan calcite are the main carbonates (average $5 \%$, up to $33 \%$ ). The kaolinite (average $2 \%$ ) and illite (average $4 \%$, up to $7 \%$ ) occur as pore-filling and pore-lining rims and are the main authigenic clay minerals. The chlorite content is relatively low. The volume of quartz overgrowths is still very low and laumontite is also rarely observed.

\section{FX Field}

The Chang 8 and 6 members in the FX field were deposited in delta front and lacustrine setting. Therefore the reservoirs are formed mainly within distributary channel sandstones, mouth bar sandstones, sheet sandstones and distal bar sandstones. Grain sorting is good and the maximum grain size is $0.28 \mathrm{~mm}$ with an average of $0.13 \mathrm{~mm}$. The sandstones are mainly fine and very fine arkose and lithic arkose. Sandstones have relatively low quartz content (average 36\%, up to $52 \%$ ). Detrital plagioclase (average $34 \%$ ) dominates over K-feldspar (average 15\%). The main types of rock fragments are quartzite, gneiss, phyllite and slate. Mica was commonly observed with an average content of $6 \%$, and a maximum of $18 \%$. The average content of calcite and ferroan calcite is $6 \%$, whereas the content of ankerite is very low. Chlorite (average 6\%) and illite (average 6\%) occur as porefilling and pore-lining rims and they are the main authigenic clay minerals. The kaolinite content is very low, less than $1 \%$. Quartz overgrowths are not frequently observed, whereas laumontite cement is very common as pore-filling cement in the Chang 7 and 6 member deposits. 


\subsection{Provenance}

\section{JY Field}

Examination of the heavy mineral suite from Chang 8 and 6 members demonstrated high garnet and zircon content (43.6\% and 50.2\% respectively) (Table 2). Quartz cathodoluminescence color is mainly brown, however blue and bluish violet quartz is also observed. Sandstones are commonly texturally submature and relatively mineralogically mature. This suggests that the JY field deposits may be near provenance. Measurements of the palaeocurrent direction in outcrops and seismic sections indicate a NW direction of palaeoflow (Fig. 3).

Framework grain characteristics and palaeocurrent data indicate that sediments in the JY field are near provenance and sediments were transported over relatively short distances. The dominant sediment sources were metamorphic rocks, however volcanic rocks also provided material for the Chang 8 and 6 member deposits.
Based on the characteristics of the ancient land of the basin margin, it can be concluded that sediment sources for the Chang 8 and 6 members in the JY field are the Alxa Group in the Ningxia province, which contains a set of gneiss, granulite, migmatites and a relatively small volume of volcanic rocks. Common rock-forming minerals are quartz, feldspar, pyroxene, hornblende and small quantities of biotite and garnet.

\section{ZJ Field}

Heavy minerals of the ZJ field deposits consist of zircon, garnet and leucoxene (average 41.9\%, 21.9\% and 32.4\% respectively). Quartz grains occur dominantly in a form of monocrystalline quartz, polycrystalline quartz and recycled quartz. Polycrystalline quartz consists of elongated original crystals characterized by sutured boundaries and brown cathodoluminescence color. Recycled quartz is characterized by overgrowths which exhibit abrasive rounding. Feldspars include primarily plagioclase however K-feldspars are also present. The plagioclase contains much higher amounts of

Table 2 Characters of heavy minerals, Chang 8 and 6 members in the Ordos Basin

\begin{tabular}{|c|c|c|c|c|c|c|c|c|c|c|}
\hline Field & Sample & Members & Zircon, \% & Garnet, \% & Titanite, $\%$ & Tourmaline, $\%$ & Rutile, \% & Epidote, \% & Leucoxene, \% & Magnetite, $\%$ \\
\hline \multirow{6}{*}{ JY } & 1 & Chang6 & 47 & 48 & 2 & 1 & 0 & 1 & 1 & 0 \\
\hline & 2 & Chang6 & 32 & 63 & 3 & 0 & 0 & 2 & 0 & 0 \\
\hline & 3 & Chang6 & 55 & 34 & 2 & 1 & 0 & 5 & 3 & 0 \\
\hline & 4 & Chang8 & 46 & 49 & 2 & 2 & 0 & 0 & 1 & 0 \\
\hline & 5 & Chang8 & 38 & 57 & 2 & 1 & 0 & 0 & 2 & 0 \\
\hline & Av. & & 43.6 & 50.2 & 2.2 & 1 & 0 & 1.6 & 1.4 & 0 \\
\hline \multirow{8}{*}{ ZJ } & 6 & Chang6 & 43 & 18 & 0 & 4 & 1 & 0 & 34 & 0 \\
\hline & 7 & Chang6 & 55 & 22 & 0 & 4 & 1 & 0 & 18 & 0 \\
\hline & 8 & Chang6 & 38 & 32 & 0 & 2 & 1 & 0 & 27 & 0 \\
\hline & 9 & Chang8 & 34 & 21 & 0 & 2 & 1 & 0 & 42 & 0 \\
\hline & 10 & Chang8 & 43 & 19 & 0 & 3 & 0 & 0 & 35 & 0 \\
\hline & 11 & Chang8 & 42 & 17 & 0 & 5 & 1 & 0 & 35 & 0 \\
\hline & 12 & Chang8 & 38 & 24 & 0 & 1 & 1 & 0 & 36 & 0 \\
\hline & Av. & & 41.9 & 21.9 & 0 & 3 & 0.9 & 0 & 32.4 & 0 \\
\hline \multirow{11}{*}{ FX } & 13 & Chang6 & 32 & 46 & 0 & 3 & 1 & 0 & 0 & 18 \\
\hline & 14 & Chang6 & 25 & 34 & 0 & 5 & 0 & 0 & 0 & 36 \\
\hline & 15 & Chang6 & 34 & 38 & 0 & 4 & 0 & 0 & 0 & 24 \\
\hline & 16 & Chang6 & 22 & 43 & 0 & 1 & 0 & 0 & 0 & 34 \\
\hline & 17 & Chang6 & 26 & 47 & 0 & 4 & 0 & 0 & 0 & 23 \\
\hline & 18 & Chang6 & 34 & 31 & 0 & 5 & 2 & 0 & 0 & 28 \\
\hline & 19 & Chang6 & 18 & 29 & 0 & 0 & 1 & 0 & 0 & 52 \\
\hline & 20 & Chang8 & 20 & 44 & 0 & 0 & 1 & 0 & 0 & 35 \\
\hline & 21 & Chang8 & 17 & 45 & 0 & 6 & 0 & 0 & 0 & 32 \\
\hline & 22 & Chang8 & 25 & 48 & 0 & 5 & 3 & 0 & 0 & 19 \\
\hline & Av. & & 25.3 & 40.5 & 0 & 3.3 & 0.8 & 0 & 0 & 30.1 \\
\hline
\end{tabular}




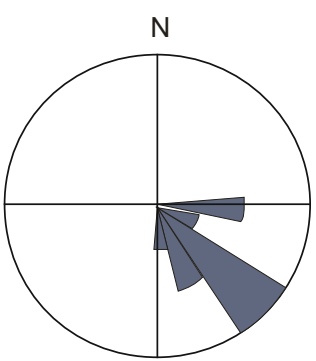

(a): Baitugang outcrop

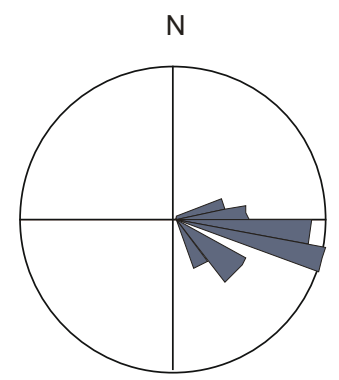

(b): Rujigou outcrop
Fig. 3 Palaeocurrent rose diagrams based on measurements from the outcrops of large dunes, current ripples and groove casts of the Chang 6 and 8 members listed in Fig. 1

$\mathrm{Na}_{2} \mathrm{O}$ than $\mathrm{CaO}$. Rock fragments are composed dominantly of schist, phyllite, plutonic igneous rocks and small fragments of carbonate rocks.

The sandstones of the Rui River outcrop located approximately $30 \mathrm{~km}$ west of the ZJ field contain quartz, feldspar and rock fragments (in average 20\%,38\% and $42 \%$ respectively). The average grain size of sandstones is 0.29 $\mathrm{mm}$. In the $\mathrm{ZJ}$ field, the amount of quartz increases to $43 \%$, and feldspar and rock fragments contents decrease to $33 \%$ and $24 \%$. Furthermore, the grain size decreases to $0.21 \mathrm{~mm}$. Grain size of the sediments in the Xifeng Oilfield, in the eastern part of the ZJ field, decreases to $0.18 \mathrm{~mm}$. The average content of quartz increases to $48 \%$ and feldspar and rock fragments decrease to $28 \%$ and $24 \%$.

Therefore it can be concluded that compositional maturity increases and grain-size of the sediments decreases eastward. Palaeocurrent direction measurements of the sediments in the Rui River outcrop section are an average of about $65^{\circ}$, which indicates a north-easterly direction of the palaeoflow.

Framework grain characteristics and palaeocurrent data indicate that the sediment source for the $\mathrm{ZJ}$ field deposits was dominated by metamorphic rocks, middle to upper Ordovician igneous rocks and Silurian, granite rocks from Hercynian and Indosinian periods and small amounts of sedimentary rocks. The sediment provenance was located along the margins of the south-western Ordos Basin.

\section{FX Field}

Heavy minerals of the Chang 8 and 6 members of the FX field are dominantly composed of garnet, zircon and magnetite (in average $40.5 \%, 25.3 \%$ and $30.1 \%$ respectively) and trace amounts of rutile and tourmaline (average $0.8 \%$ and $3.3 \%$ ). Under the microscope many quartz grains display undulatory extinction, a pattern of sweeping extinction as the stage is rotated. Some quartz grains contain inclusions of either garnet or zircon. Quartz grains display blue to bluish violet cathodoluminescence color. Feldspars occur in form of plagioclase and K-feldspar minerals in a proportion of 2 to 3. Rock fragments dominantly consist of phyllite, slate and biotite. The palaeocurrent forming the sediments in the FX field flowed from north to south.

Framework grain characteristics and palaeocurrent data indicate that the sediment source for the FX field deposits was metamorphic rocks located in the northern part of the Ordos Basin. The rocks are characterized by high proportions of feldspar, garnet, epidote, sphene, biotite and relatively low quartz content.

\section{Diagenesis}

\subsection{Mechanical compaction}

Mechanical compaction had the dominant effect on porosity destruction in sandstones of the Chang 8 and 6 members which is linked to the amount of ductile grains. The proportion of ductile grains in sandstones has a profound effect on reservoir quality.

Ductile grains are composed dominantly of biotite, slate and schist fragments. Fig. 4(a) illustrates compaction effects in terms of volume loss due to ductile and flexible grain deformation. In the centre of the thin section, intergranular pores can be observed and they have been preserved due to insignificant deformation of rigid grains. Whereas tightly packed grains seen in the peripheral parts of the thin section are due to ductile deformation. Cements formed as a result of eodiagenetic processes, such as chlorite rims, calcite and laumontite, may impede mechanical compaction during burial (Fig. 4(b)).

\subsection{Cementation}

\section{Carbonate cementation}

Reservoir quality is controlled primarily by formation of carbonate cements in the Chang 8 and 6 members. They are mainly composed of calcite, ferroan calcite and ankerite. Poikilitic calcite cement encloses fragments of grains and fills intergranular pores to form tight sandstones (Fig. 4(c)). Petrographic evidence supports the hypothesis that the formation of chlorite rims precedes the formation of ferroan calcite (Fig. 4(d)). Analysis of the samples from the Chang 8 and 6 members suggests that carbonate cement dissolution was not extensive.

Carbonate cements were commonly observed in the deposits of JX, JY and ZJ fields where the highest carbonate cements content was identified in the $\mathrm{ZJ}$ field deposits because a significant quantity of carbonate grains in the sandstones decreases the chemical and kinetic barriers to cement precipitation (Taylor et al, 2004).

\section{Chlorite cementation}

The authigenic growth of chlorite rims is commonly observed in the sandstones of the Chang 8 and 6 members. However chlorite rims are typically absent along contacts between framework grains. The thicknesses of chlorite rims are constant which suggests that the chlorite rims were formed during an early stage of the burial history after framework grains came into contact with each other. However the chlorite rims clearly developed at two different stages: the early stage chlorite is poorly crystallized, and the later stage is better crystallized. During the early stage chlorite crystallized replacing Fe-rich clay precursors, whereas during the later stage radially oriented authigenic chlorites crystallized upon the previous chlorite coating. The first stage would occur at the initial phase of the mechanical compaction when rocks were not thoroughly consolidated. The second stage would occur at greater burial depth and resulted in the growth of 

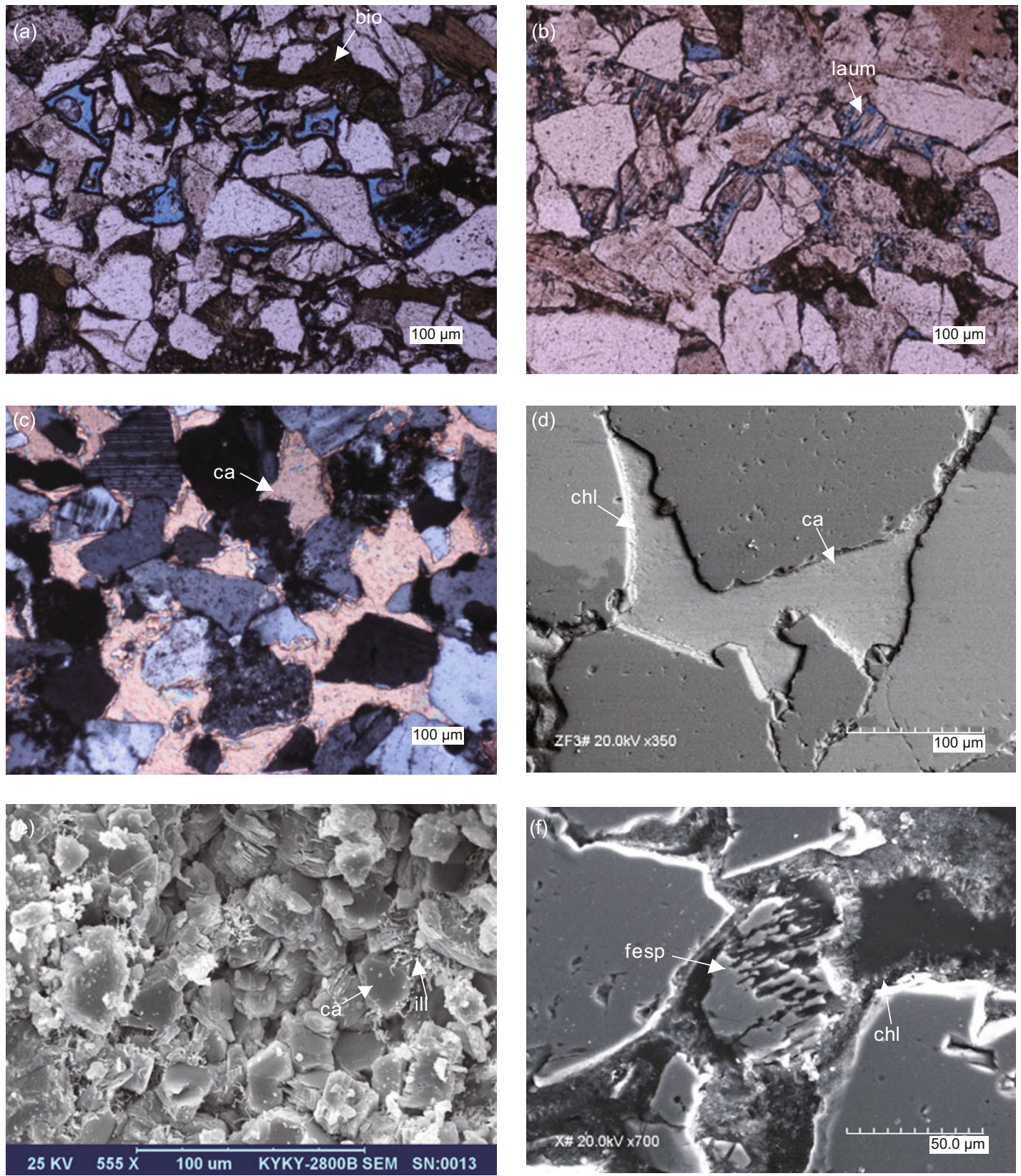

Fig. 4 Thin-section photomicrographs ( $\mathrm{a}, \mathrm{b}, \mathrm{c})$ and scanning electron microscope photographs (d, e, f) of reservoir sediments from the Yanchang Formation, Ordos Basin. (a) Different mechanical compaction owing to different contents of ductile and flexible biotite (bio). Intergranular pores are preserved as the consequence of central weak compaction, PPL. (b) Poikilotopic laumontite (laum) cement lead to minor mechanical compaction, PPL. (c) Poikilitic calcite (ca) cement encloses fragment grains to form tight sandstones, XPL. (d) Chlorite (chl) rims affected by calcite (ca) cementation. (e) Part of kaolinite (kao) may be replaced by fibrous illite (ill). (f) Dissolution of feldspar (fesp) grains

authigenic coarse grained euhedral chlorites.

Chlorite rims change progressively in arrangement and texture of the particles from the contact with the substrate to the centre of the pore. The Fe content in the centre of the pores is the same as that at the contact with the substrate, which suggests that $\mathrm{Fe}$ ions are conserved during the precipitation of chlorite rims, however at the same time, $\mathrm{Fe}$ ions are formed by hydration of Fe-rich precursor. Therefore it can be concluded that the chlorite rims formed in a partially closed diagenetic system (Ding et al, 2010).

Chlorite rims are very common in the FX field sediments and can also be observed in the JY field sediments (Table 3), particularly in the south part of the field. In contrast, the ZJ field sediments do not contain a significant amount of chlorite rims.

\section{Kaolinite cementation}

Kaolinite cement is commonly observed in the sediments of the JY and ZJ fields, while it is rare in the FX field sediments (Table 3). Authigenic kaolinite is formed by dissolving feldspar and mica and its formation is usually related to meteoric water (Anjos et al, 2000; Franca et al, 2003; Higgs et al, 2007). Dissolution of feldspars may result in in situ crystallization of kaolinite with little or no increase in porosity, however leading to a decrease in 
Table 3 The relative contents of clay minerals in the sandstones of Chang 8 and 6 members

\begin{tabular}{|c|c|c|c|c|c|c|c|c|c|c|c|c|c|c|}
\hline \multirow{3}{*}{ Field } & \multirow{3}{*}{ Members } & \multirow{3}{*}{$\begin{array}{c}\text { Sample } \\
(n)\end{array}$} & \multicolumn{12}{|c|}{ Content of clay mineral, $\%$} \\
\hline & & & \multicolumn{3}{|c|}{ Illite } & \multicolumn{3}{|c|}{ Kaolinite } & \multicolumn{3}{|c|}{ Chlorite } & \multicolumn{3}{|c|}{ Illite/Smectite } \\
\hline & & & Max & Min & Aver & Max & Min & Aver & Max & Min & Aver & Max & Min & Aver \\
\hline \multirow{2}{*}{ FX } & Chang 6 & 5 & 13 & 3 & 8 & 6 & 0 & 3 & 100 & 62 & 79 & 27 & 7 & 15 \\
\hline & Chang 8 & 6 & 35 & 16 & 24 & 5 & 0 & 2 & 56 & 25 & 44 & 18 & 40 & 31 \\
\hline \multirow{2}{*}{ ZJ } & Chang 6 & 3 & 29 & 16 & 25 & 64 & 35 & 52 & 9 & 7 & 8 & 38 & 10 & 15 \\
\hline & Chang 8 & 10 & 9 & 5 & 7 & 40 & 16 & 26 & 44 & 21 & 35 & 37 & 18 & 32 \\
\hline \multirow{2}{*}{ JY } & Chang 6 & 12 & 27 & 14 & 20 & 39 & 17 & 28 & 52 & 20 & 32 & 29 & 12 & 20 \\
\hline & Chang 8 & 3 & 30 & 15 & 25 & 47 & 22 & 34 & 56 & 23 & 30 & 32 & 10 & 11 \\
\hline
\end{tabular}

Notes: $n$ is the number of samples

permeability. The pore spaces between the kaolinite crystals may be too small to be filled with oil and as a consequence, water saturation is increased. On the other hand, porosity of sandstones could be increased by migration of kaolinite by pore waters in shallow depths. In thin section, illite has been observed to grow and partially replace kaolinite by filling the intracrystalline pore system and leading to the kaolinite crystals becoming fibrous (Fig. 4(e)).

\section{Laumontite cementation}

The content of laumontite ranges in average from $6 \%$ to $12 \%$ (maximum $20 \%$ ) and it is present in the Chang 3 , 4+5, 6 and 7 members of the FX field deposits; however it is rarely observed in the ZJ and JY field deposits. Dissolution of laumontite cement is noticeable in the Chang 6 Member of the Ansai and Zhijing fields located in the north of the FX field with known 100 million tons of oil reserves.

It is believed that the sweet spots form due to dissolution of laumontite cement in the tight sandstones (Bai et al, 2009). In general, laumontite cement is found in well sorted, fine to middle-grained sandstones with low matrix content.

Laumontite can be classified according to its occurrence and origin into two categories: poikilotopic laumontite cement and replaced laumontite. Due to dissolution along cleavage of poikilotopic laumontite, secondary porosity is formed. Commonly plagioclase is replaced along cleavage by laumontite. Another observation is the type of feldspars in arkoses with laumontite cement, which are usually albite and K-feldspars but not anorthite.

\subsection{Dissolution}

Secondary solution porosity is very common in the Chang 8 and 6 members and it is caused by dissolution of metastable framework grains (Fig. 4(f)) and laumontite cement. However the amount of solution porosity differs among sediments encountered within the three study fields (Fig. 5). The solution porosity developed in the JY field sediments amounts to $2.5 \%$ by volume and was developed due to dissolution of feldspars and volcanic rock fragments in the amount of $2 \%$ and $0.5 \%$ respectively. In the $\mathrm{ZJ}$ field sediments solution porosity amounts to $3 \%$, however, in addition to the dissolution of feldspars $(1.5 \%)$ and volcanic rock fragments $(1 \%)$, it was also developed due to the dissolution of carbonate rock fragments $(0.5 \%)$. The highest solution (4.7\%) was developed in the sediments of the FX field where dissolution of feldspars and laumontite cement took place $(3 \%$ and $1.5 \%$ respectively).

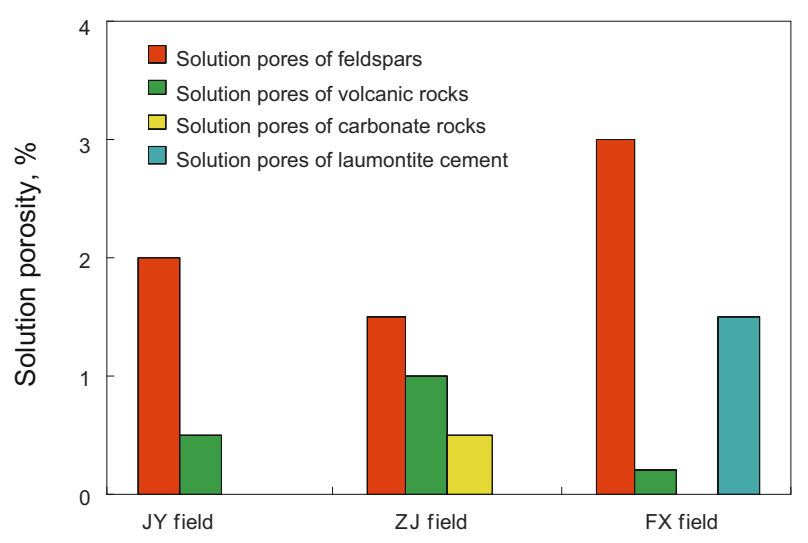

Fig. 5 The proportion of solution pores of different fields

\section{Discussion}

\subsection{Relationship between the sediment provenance and mechanical compaction}

Three main factors can control mechanical compaction in sandstones: 1) vertical effective stress, 2) the content and quantity of ductile grains and 3) cements of eodiagenetic origin (Bloch et al, 2002).

It is believed that porosity decreases about $26 \%$ at $2 \mathrm{~km}$ depth, initially due to the mechanical compaction under increasing effective stress. Below this point $(2 \mathrm{~km})$, compaction in rigid-grained sands stabilizes to very low rates (Lander and Walderhaug, 1999; Paxton et al, 2002; Ajdukiewicz and Lander, 2010). Based on burial history studies ( $\mathrm{Li}$ et al, 2006), the maximum burial depth of the Chang 8 and 6 members exceeded $2 \mathrm{~km}$ at the end of early Cretaceous.

The rate of mechanical compaction in sandstones is mainly controlled by content of ductile and flexible grains. 
Sandstones with ductile grains experience more extensive compaction than rigid-grained counterparts under the same burial conditions. The effect of ductile grains on mechanical compaction is a function of the mechanical properties of the rock and the volume of ductile grains, as well as effective stress (Pittman and Larese, 1991). The relationship between ductile grains and burial compaction can be studied by intergranular volume (IGV). IGV is a good index of the compaction state of sandstones and provides an indication of the maximum porosity that can be expected $(\mathrm{IGV}=$ intergranular porosity + pore-filling cements + matrix; expressed in the percentage of bulk-rock volume).

The initial porosity of sandstones is believed to be $40 \%$. Samples of sediments with low calcite and laumontite cements were chosen for analysis. A plot of intergranular volume versus cement volume indicates that compaction is greater when the content of ductile grains in sandstones exceeds $20 \%$. Consequently, over $75 \%$ of the porosity may be destroyed. In general, porosity of sandstones with a ductile grains content of over $20 \%$ is less than $8 \%$. Nevertheless, compaction is still significant when ductile grains content is between $10 \%$ and $20 \%$. The porosity of those sandstones typically amounts to up to $10 \%$. However, when the content of ductile grains is less than $10 \%$ and the volume of calcite and laumontite cements is low, the porosity of sandstones often exceeds $10 \%$ (Fig. 6).

Thus it can be shown that the content of ductile and flexible grains controls the mechanical compaction and consequently it has an effect on the overall reservoir quality.

The sediment source of the Chang 8 and 6 members in the JY field is composed of gneiss, granulite, migmatites, and a small volume of volcanic rocks. The content of quartz and feldspars is relatively high, whereas ductile grains content is minor. Despite the deepest burial of the sediments, the mechanical compaction which affected the sediments of the JY field is the weakest compared to the other fields.

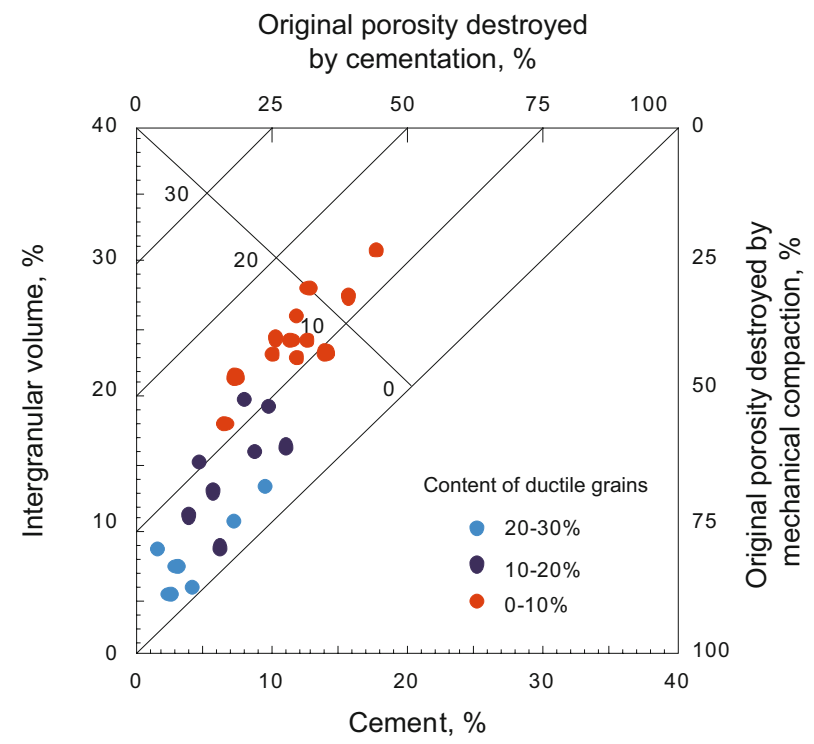

Fig. 6 Plot of intergranular volume (IGV) versus cement volume of sandstone samples from the Chang 8 and 6 members
The sediment source of the Chang 8 and 6 members in the ZJ field consists of metamorphic and igneous rocks. Mechanical compaction increases with burial depth because of large amount of ductile and flexible grains in the sandstones, such as slate and phyllite.

The sediment source of the Chang 8 and 6 members in the FX field consists of granulite, which can be weathered to form large quantity of biotite. Additionally, the grain size of the sediments is fine to very fine, which results in the most severe degradation of porosity due to mechanical compaction in this field.

\subsection{Relationship between the sediment provenance and formation of chlorite rims}

Chlorite is the most important diagenetic clay mineral in sandstones. The occurrence and amount of chlorite rims in sandstones is significant for porosity preservation, especially in deep tight reservoirs (Ehrenberg, 1993; Tian et al, 2008). The importance of chlorite rims in preserving porosity in sandstones has been recognized in numerous studies. Firstly, chlorite rims can impede mechanical compaction and secondly, they can prevent the formation of quartz overgrowths at greater depth (Ehrenberg, 1993; Paxton et al, 2002; Anjos et al, 2003; Berger et al, 2009). Authigenic chlorite rims are commonly iron-rich, but magnesium-rich chlorite rims also have been reported (Kugler and McHugh, 1990; Hillier, 1994). An essential element for forming chlorite rims cements is iron. Generally, the concentration of iron in sea water and lake water is very low, whereas fluvial environment is found to contain high concentration of this element.

Three sources of iron for chlorite cement formation have been recognized (Ehrenberg, 1993; Hillier, 1994; Grigsby, 2001; Huang et al, 2004). Firstly, the dissolution of ironand magnesium-rich unstable components such as biotite, amphibole and volcanic rock fragments in the eogenetic realm can offer large quantities of iron and magnesium for forming chlorite cements (De Ros et al, 1994; Remy, 1994). On the other hand, chlorite cements can be formed continuously in open and semi-closed diagenetic systems due to abundant sources of iron and magnesium. Secondly, chlorite cements can be formed by transforming mechanically infiltrated clays, eogenetic authigenic smectites and kaolinite into environments rich in iron and magnesium. Lastly, chlorite cements can be formed by alteration of non-clay minerals such as biotite, amphibole and volcanic rock fragments when they come into contact with iron-rich pore waters.

Dissolution of iron- and magnesium-rich unstable minerals is the main mechanism which leads to the formation of chlorite cements. Therefore a close relationship exists between the formation of chlorite cements and sediment source, which can supply biotite, amphibole and volcanic rock fragments into the environment of deposition.

The sediment source of the Chang 8 and 6 members in the JY field consists of many basic volcanic rocks, which can supply iron and magnesium to form chlorite cements. In the north, the Chang 8 and 6 members were deposited in delta plain environments whereas the southern sediments were 
deposited in delta front settings due to the proximity of the Alxa Uplift in the north. Apart from the fact that both of them are supplied with the dissolved iron as discussed before, the southern sediments had additional supply from amorphous iron hydroxides carried in the river and flocculated by lake water at the river mouth, so the content of chlorite cements would have been higher than the northern part of the JY field.

The sediment source of the FX field deposits was mainly gneiss which can supply large quantity of biotite, and the Yanchang Formation deposits are interbedded with tuff. Biotite and tuff can supply significant amount of iron and magnesium. Furthermore, the Chang 8 and 6 members were deposited in delta front and prodelta settings, which also provided favourable conditions for the formation of chlorite cements in the FX field sediments.

The sediment source of the ZJ field deposits was metamorphic rocks and granite leading to relatively low biotite, amphibole and volcanic rock fragments content. Consequently, chlorite cements are rarely observed because of limited supply of iron and magnesium.

\subsection{Relationship between the sediment provenance and kaolinite cement formation}

Many detailed studies confirm that kaolinite is formed by dissolution of feldspars and mica. Transport of dissolved ions and suspended solids (like $\mathrm{Ca}^{2+}, \mathrm{Na}^{+}$and $\mathrm{SiO}_{2}$ ) by diffusion and fluid flow (advection) is one of the most important factors in controlling the mechanism of kaolinite formation. Decaying organic matter near the surface produces $\mathrm{CO}_{2}$, which is added to the meteoric waters making it more acidic. Meteoric water dissolves unstable minerals like feldspars, mica and carbonate rocks. It has been confirmed that plagioclase has a minimum Gibbs free energy at low temperature compared with K-feldspar and albite (Huang et al, 2009). Therefore, plagioclase is unstable in low temperature settings.

At the same time, in open low temperature systems, transport of $\mathrm{K}^{+}$by diffusion and fluid flow commonly decreases the overall concentration of the $\mathrm{K}^{+}$in place and consequently prevents the formation of illite (Chuhan et al, 2000; 2001). Furthermore, dissolved aluminium and some of the silica is precipitated in the form of kaolinite, which in overall leads to a minor increase in porosity but a reduction in permeability.

Because of the large quantity of plagioclase in the sandstones, kaolinite is a common clay mineral in the Chang 8 and 6 members in the Ordos Basin. The formation of kaolinite is related to both the sediment source and depositional setting. Dissolution and kaolinization of detrital feldspars and micas occur in the landward extension of the deltaic deposits in association with more extensive meteoric water percolation (Çağatay et al, 1996).

The Chang 8 and 6 members in the JY field were deposited as delta-plain and delta-front facies. Abundant kaolinite observed in these sediments was formed due to dissolution of plagioclase minerals by meteoric water. The Chang 8 and 6 members in the ZJ field were deposited as delta-front facies, and similarly, dissolution of plagioclase by meteoric water led to a high concentration of kaolinite.
By contrast, the FX field deposits are characterized by a near absence of kaolinite because of prodelta and delta front facies which resulted in weak meteoric water dissolution.

\subsection{Relationship between the sediment provenance and formation of laumontite cements}

The formation of laumontite requires a high concentration of $\mathrm{SiO}_{2}$ and alkaline ions. Laumontite cement may be formed by hydration of volcanic rocks or albitization of plagioclase (Yang and Qiu, 2002; Bai et al, 2009).

The distribution of laumontite-rich sandstones in the study area is controlled by the sediment source from the Yinshan Uplift in the northern Ordos Basin. Intense magmatic intrusions and volcanic eruptions took place in the Yinshan Uplift area during the late Permian till Triassic times. Therefore tuff and volcanic rock fragments are commonly found in the Yanchang Formation in the northern part of the FX field. Hydration of glassy fragments of tuff and volcanic rock fragments can form cations such as $\mathrm{Ca}^{2+}, \mathrm{Mg}^{2+}, \mathrm{Na}^{+}$ and $\mathrm{Fe}^{3+} \cdot \mathrm{Mg}^{2+}$ and $\mathrm{Fe}^{3+}$ ions can form chlorite (Anjos et al, 2003), and $\mathrm{Ca}^{2+}$ and $\mathrm{Na}^{+}$form phillipsite. Finally, phillipsite can dehydrate to form stable laumontite in later stages of diagenesis at higher temperatures during burial.

Laumontite can be formed by albitization of plagioclase. The following equation illustrates a reaction with anorthite:

$$
\begin{aligned}
& 2 \mathrm{CaAl}_{2} \mathrm{Si}_{2} \mathrm{O}_{8}+2 \mathrm{Na}^{+} \cdot 4 \mathrm{H}_{2} \mathrm{O}+6 \mathrm{SiO}_{2} \\
& =2 \mathrm{NaAlSi}_{3} \mathrm{O}_{8}+\mathrm{CaAl}_{2} \mathrm{Si}_{4} \mathrm{O}_{12} \cdot 4 \mathrm{H}_{2} \mathrm{O}+\mathrm{Ca}^{2+}
\end{aligned}
$$

As previously indicated, the formation of laumontite is related to volcanic rocks, plagioclase and sodium-rich pore waters in sandstones. The provenance of the Yinshan Uplift deposits consisted of metamorphic rocks, tuff and few volcanic rock fragments, which can offer large quantity of plagioclase and glassy fragments.

In summary, laumontite-rich sandstones are very common within the sediments of the FX field, however relatively rare in the $\mathrm{ZJ}$ and $\mathrm{JY}$ fields.

\subsection{Relationship between the sediment provenance and dissolution processes}

Secondary porosity created by the dissolution of framework grains and pore-filling cements is often related to meteoric waters (Morad et al, 2000; Wilkinson et al, 2006; Taylor et al, 2010) or organic acids (Schmidt and McDonald, 1979). An additional important factor regarding the dissolution is the type of dissolved framework grains and cements. Common dissolved framework grains and cements are feldspars, volcanic rock fragments, carbonate rock fragments and laumontite cement.

Plagioclase is unstable in low temperatures therefore meteoric waters which percolate the sediments, dissolve plagioclase to form kaolinite in the early diagenetic process. The dissolved components can be transported out of the low temperature open reaction system, leading to a net increase in porosity without a reduction of permeability (Taylor et al, 2010). However, K-feldspar and kaolinite are no longer stable together with increasing $\mathrm{K}^{+} / \mathrm{H}^{+}$ratio and higher temperature during later diagenesis. K-feldspars can be dissolved, and 
kaolinite is replaced by illite. K-feldspar dissolution has a detrimental effect on reservoir quality, because the dissolved components cannot be transported out of the reaction system in a closed system, resulting in an insignificant change of total porosity, but a significant decrease of permeability because of high specific surface area.

Volcanic rock fragments are unstable, therefore can be dissolved to form secondary porosity during diagenesis. Carbonate rock fragments are also unstable in the early diagenesis process, and can be easily dissolved to form mould pores. Laumontite cement is also easily dissolved to form intraparticle pores.

The dissolution of feldspars is common in the Chang 8 and 6 members in the Ordos Basin because of the type of sediment source and depositional setting. Furthermore, the dissolution of feldspars is more significant in the JY field and FX field deposits. The dissolution of volcanic rock fragments is commonly observed in the JY field and ZJ field deposits due to percolation of meteoric water through the sediments. The dissolution of carbonate rock fragments is only observed in the ZJ field deposits and it is controlled by sediment source type. The dissolution of laumontite cement is only found in the FX field deposits.

\section{Conclusions}

As previously indicated, the type of framework grains is highly controlled by the sediment provenance and it controls diagenetic modifications which are likely to affect the reservoir. Furthermore, different composition of siliciclastic reservoirs governs the nature and degree of diverse diagenetic processes within the same geothermal gradient conditions or depositional setting.

1) The sediment provenance of the Chang 8 and 6 members in the JY field was dominated by gneiss, granulite, migmatites and a small volume of volcanic rocks. As a result, the sandstones in the JY field are composed primarily of quartz but the amount of feldspars and rock fragments is still high. Typical processes affecting the sandstones in the JY field are weak mechanical compaction and significant dissolution of feldspars and rock fragments. Finally, the content of kaolinite is high but the content of chlorite is low in the northern part of the JY field.

2) The sediment provenance of the Chang 8 and 6 members in the ZJ field consists of gneiss and igneous rocks. Due to a high proportion of ductile and flexible rock fragments, the deposits are significantly compacted mechanically. Within clay minerals, the content of kaolinite is high, whereas chlorite is rarely observed. Moderate secondary porosity was developed due to dissolution of feldspars, volcanic and carbonate rock fragments.

3) The sediment provenance of the Chang 8 and 6 members in the FX field is gneissic and a small volume of volcanic rocks. Major minerals composing the sandstones are feldspars and biotite. As a result of high biotite content, considerable mechanical compaction affected the sandstones. Chlorite is a commonly observed clay mineral, whereas the amount of kaolinite is insignificant, which is due to illitization of kaolinite in high temperatures. Another important cement of the FX field sandstones is laumontite. Secondary porosity developed due to the dissolution of feldspars and laumontite cement is commonly observed.

\section{Acknowledgements}

This work is supported by the National Natural Science Foundation of China (No. 40972098, 41272168) and China Postdoctoral Science Foundation (2012M511941).

\section{References}

Ajdukiewicz J M and Lander R H. Sandstone reservoir quality prediction: The state of the art. AAPG Bulletin. 2010. 94(8): 10831091

Anjos S M C, DeRos L F, DeSouza R S, et al. Depositional and diagenetic controls on the reservoir quality of Lower Cretaceous Pendência sandstones, Potiguar rift basin, Brazil. AAPG Bulletin. 2000. 84(11): 1719-1742

Anjos S M C, DeRos L F and Silva C M A. Chlorite authigenesis and porosity preservation in the Upper Cretaceous marine sandstones of the Santos Basin, offshore eastern Brazil. International Association of Sedimentology. 2003. 34(2): 291-316

Bai Q H, Liu Y Q and Fan T T. Genesis and distribution of laumontite in Yanchang Formation of Upper Triassic in Ordos Basin. Northwestern Geology. 2009. 42(2): 100-107 (in Chinese)

Berger A, Gier S and Krois P. Porosity-preserving chlorite cements in shallow-marine volcaniclastic sandstones: Evidence from Cretaceous sandstones of the Sawan gas field, Pakistan. AAPG Bulletin. 2009. 93(5): 595-615

Bloch S, Lander R H and Bonnell L. Anomalously high porosity and permeability in deeply buried sandstone reservoirs: Origin and predictability. AAPG Bulletin. 2002. 86(2): 301-328

Çağatay M N, Saner S, Al-Saiyed I, et al. Diagenesis of the Safaniya sandstone member (mid-Cretaceous) in Saudi Arabia. Sedimentary Geology. 1996. 105(3-4): 221-239

Caja M A, Marfil R, Garcia D, et al. Provenance of siliciclastic and hybrid turbiditic arenites of the Eocene Hecho Group, Spanish Pyrenees: Implications for the tectonic evolution of a foreland basin. Basin Research. 2010. 22(2): 157-180

Chuhan F A, Bjørlykke K and Lowrey C J. The role of provenance in illitization of deeply buried reservoir sandstones from Haltenbanken and north Viking Graben, offshore Norway. Marine and Petroleum Geology. 2000. 17(6): 673-689

Chuhan F A, Bjørlykke K and Lowrey C J. Closed system burial diagenesis in reservoir sandstones: Examples from the Garn Formation at Haltenbanken area, offshore mid-Norway. Journal of Sedimentary Research. 2001. 71(1): 15-26

De Ros L F, Anjos S M C and Morad S. Authigenesis of amphibole and its relationship to the diagenetic evolution of Lower Cretaceous sandstones of the Potiguar rift basin, northeastern Brazil. Sedimentary Geology. 1994. 88(3-4): 253-266

Ding X Q, Zhang S N, Ge P L, et al. Relationship between reservoir properties and chlorite rims: A case study from Yanchang Formation of South Ordos Basin, North China. Geological Journal of China Universities. 2010. 16(2): 247-254 (in Chinese)

Ehrenberg S N. Preservation of anomalously high porosity in deeply buried sandstones by grain-coating chlorite: Examples from the Norwegian continental shelf. AAPG Bulletin. 1993. 77(7): 12601286

Fontana D, McBride E F and Kugler R. Diagenesis and porosity evolution of submarine-fan and basin-plain sandstones, MarnosoArenacea Formation, northern Apennines, Italy. Bulletin of Canadian Petroleum Geology. 1986. 34(3): 313-328 
Fontana D, Zuffa G G and Garzanti E. The interaction of eustasy and tectonism from provenance studies of the Eocene Hecho Group turbidite complex (south-central Pyrenees, Spain). Basin Research. 1989. 2(4): 223-237

Franca A B, Araujo L M, Maynard J B, et al. Secondary porosity formed by deep meteoric leaching: Botucatu eolianite, southern South America. AAPG Bulletin. 2003. 87(7): 1073-1082

Grigsby J D. Origin and growth mechanism of authigenic chlorite in sandstones of the lower Vicksburg Formation, south Texas. Journal of Sedimentary Research. 2001. 71(1): 27-36

Hawlader H M. Diagenesis and reservoir potential of volcanogenic sandstones - Cretaceous of the Surat Basin, Australia. Sedimentary Geology. 1990. 66(3-4): 181-195

Higgs K E, Zwingmann H, Reyes A G, et al. Diagenesis, porosity evolution, and petroleum emplacement in tight gas reservoirs, Taranaki Basin, New Zealand. Journal of Sedimentary Research. 2007. 77(12): 1003-1025

Hillier S. Pore-lining chlorites in siliciclastic reservoir sandstones: Electron microprobe, SEM, and XRD data, and implications for their origin. Clay Minerals. 1994. 29(4): 665-679

Huang S J, Huang K K, Feng W L, et al. Mass exchanges among feldspar, kaolinite and illite and their influences on secondary porosity formation in clastic diagenesis-A case study on the Upper Paleozoic, Ordos Basin and Xujiahe Formation, Western Sichuan Depression. Geochimica. 2009. 38(5): 498-506 (in Chinese)

Huang S J, Xie L W, Zhang M, et al. Formation mechanism of authigenic chlorite and relation to preservation of porosity in nonmarine Triassic reservoir sandstones, Ordos Basin and Sichuan Basin, China. Journal of Chengdu University of Technology (Science \& Technology Edition). 2004. 31(3): 273-281 (in Chinese)

Kugler R L and McHugh A. Regional diagenetic variation in Norphlet sandstone: Implications for reservoir quality and origin of porosity. Transactions of the Gulf Coast Association of Geological Societies. 1990. 40(9): 411-423

Lander R H and Bonnell L M. A model for fibrous illite nucleation and growth in sandstones. AAPG Bulletin. 2010. 94(8): 1161-1187

Lander R H and Walderhaug O. Predicting porosity through simulating sandstone compaction and quartz cementation. AAPG Bulletin. 1999. 83(3): 433-449

Li R X, Xi S L and Di L J. Oil/gas reservoiring phases determined through petrographic analysis of hydrocarbon inclusions in reservoirs: Taking Longdong oilfield, Ordos Basin, as an example. Oil \& Gas Geology. 2006. 27(2): 194-200 (in Chinese)

Mansurbeg H, Caja M A, Marfil R, et al. Diagenetic evolution and porosity destruction of turbiditic hybrid arenites and siliciclastic sandstones of foreland basins: Evidence from the Eocene Hecho Group, Pyrenees, Spain. Journal of Sedimentary Research. 2009.
79(9): 711-735

Morad S, Ketzer J M and De Ros L F. Spatial and temporal distribution of diagenetic alterations in siliciclastic rocks: Implications for mass transfer in sedimentary basins. Sedimentology. 2000. 47(Supplement): $95-120$

Paxton S T, Szabo J O, Ajdukiewicz J M, et al. Construction of an intergranular volume compaction curve for evaluating and predicting compaction and porosity loss in rigid-grain sandstone reservoirs. AAPG Bulletin. 2002. 86(12): 2047-2067

Pirrie D, Ditchfield P W and Marshall J D. Burial diagenesis and porefluid evolution in a Mesozoic back-arc basin: The Marambio Group, Vega Island, Antarctica. Journal of Sedimentary Research. 1994. 64(3a): 541-552

Pittman E D and Larese R E. Compaction of lithic sands: Experimental results and applications. AAPG Bulletin. 1991. 75(8): 1279-1299

Remy R R. Porosity reduction and major controls on diagenesis of Cretaceous-Paleocene volcaniclastic and arkosic sandstone, Middle Park Basin, Colorado. Journal of Sedimentary Research. 1994. 64(4): 797-806

Schmidt V and McDonald D A. The role of secondary porosity in the course of sandstone diagenesis. In: Scholle P A and Schluger P R, eds., Aspects of Diagenesis. SEPM Special Publication. 1979. 26: 175-207

Taylor K G, Gawthorpe R L and Fannon-Howell S. Basin-scale diagenetic alteration of shoreface sandstones in the Upper Cretaceous Spring Canyon and Aberdeen Members, Blackhawk Formation, Book Cliffs, Utah. Sedimentary Geology. 2004. 172(1-2): 99-115

Taylor T R, Giles M R, Hathon L A, et al. Sandstone diagenesis and reservoir quality prediction: Models, myths, and reality. AAPG Bulletin. 2010. 94(8): 1093-1132

Tian J F, Chen Z L, Fan Y F, et al. The occurrence, growth mechanism and distribution of authigenic chlorite in sandstone. Bulletin of Mineralogy, Petrology and Geochemistry. 2008. 27(2): 200-207 (in Chinese)

Warren E A and Pulham A J. Anomalous porosity and permeability preservation in deeply buried Tertiary and Mesozoic sandstones in the Cusiana field, Llanos Foothills, Colombia. Journal of Sedimentary Research. 2001. 71(1): 2-14

Wilkinson M, Haszeldine R S and Fallick A E. Jurassic and Cretaceous clays of the northern and central North Sea hydrocarbon reservoirs reviewed. Clay Minerals. 2006. 41(1): 151-186

Yang X P and Qiu Y N. Formation process and distribution of laumontite in Yanchang Formation (Upper Triassic) of Ordos Basin. Acta Sedimentologica Sinica. 2002. 20(4): 628-632 (in Chinese)

Zuffa G G, Cibin U and Giulio A D. Arenite petrography in sequence stratigraphy. The Journal of Geology. 1995. 103(4): 451-459

(Edited by Hao Jie) 